\title{
Faktor-Faktor yang Berhubungan dengan Kecendrungan Turnover Perawat di Rumah Sakit Islam "Ibnu Sina" Yarsi Sumbar Bukittinggi
}

\author{
Bambang Aryanto $^{a}$, Reni Prima Gusty ${ }^{b}$, Yulastri Arif ${ }^{b}$ \\ ${ }^{\mathrm{a}}$ Rumah Sakit Ibnu Sina Bukittinggi \\ ${ }^{\mathrm{b}}$ Universitas Andalas
}

\begin{abstract}
High turnover is a problem in the management of human resources at the hospital. Nurse turnover rate in hospitals Islam "Ibn Sina "Yarsi Bukittinggi West Sumatra tend to rise each year, the data of 2009 and 2010 were $21.3 \%$ and $24.3 \%$. The purpose of research is to identify factors associated with nurse turnover trends in Islamic Hospital "Ibn Sina "Yarsi Bukittinggi West Sumatra. This type of research with a descriptive analytic cross sectional study approach. Samples numbered 75 people. Retrieval of data using questionnaires. Data analysis using Chi Square. The results showed as much as $54.7 \%$ of nurses have a tendency turnover, there is a relationship between external factors, namely the availability of jobs in other institutions with turnover tendency ( $p$ - value 0.039 ) and there was no relationship between internal organizational factors ( size of the organization, leadership, compensation, job satisfaction, career development, job weights, centralization and the individual factors of employees ) with a turnover tendency. To reduce nurse turnover required the attention of hospital administrators in the review of programs - programs that can reduce nurse turnover among other improvements in nursing leadership, career development programs and efforts to increase nurse job satisfaction .
\end{abstract}

Keywords: nurse turnover, management, human resources

\begin{abstract}
Abstrak : Turnover yang tinggi merupakan masalah dalam pengelolaan sumber daya manusia di rumah sakit. Angka turnover perawat di Rumah Sakit Islam "Ibnu Sina" Yarsi Sumbar Bukittinggi tiap tahun cenderung naik, data tahun 2009 dan 2010 adalah $21,3 \%$ dan $24,3 \%$. Tujuan penelitian adalah mengidentifikasi faktor-faktor yang berhubungan dengan kecendrungan turnover perawat di Rumah Sakit Islam "Ibnu Sina" Yarsi Sumbar Bukittinggi. Jenis penelitian ini deskriptik analitik dengan pendekatan Cross Sectional Study. Sampel berjumlah 75 orang. Pengambilan data mengunakan kuesioner. Analisis data menggunakan Chi Square. Hasil penelitian didapatkan sebanyak $54,7 \%$ perawat memiliki kecendrungan turnover, terdapat hubungan antara faktor eksternal yaitu ketersediaan lapangan kerja di institusi lain dengan kecendrungan turnover ( $p$-value 0.039) dan tidak ada hubungan antara faktor internal organisasi (ukuran organisasi, kepemimpinan, kompensasi, kepuasan kerja, pengembangan karir, bobot pekerjaan, sentralisasi dan faktor individu karyawan ) dengan kecendrungan turnover. Untuk mengurangi turnover perawat diperlukan perhatian pimpinan rumah sakit dalam kajian ulang tentang program - program yang dapat mengurangi turnover perawat antara lain perbaikan kepemimpinan dalam keperawatan, program pengembangan karir dan upaya dalam meningkatkan kepuasan kerja perawat.
\end{abstract}

Kata kunci : turnover perawat, manajemen, sumber daya manusia. 
Turnover berasal dari kamus Inggris-Indonesia berarti pergantian (Echols, John \& Hassan Shadilly, 1975:608). Ivancevich (1995), menjelaskan bahwa turnover adalah keluarnya karyawan dari suatu organisasi yang diikuti oleh masuknya karyawan penganti. Wether (1996), lebih memfokuskan pengertian turnover sebagai kehilangan karyawan oleh suatu organisasi. Mobley (1986) mendefinisikan turnover adalah keluarnya karyawan dari suatu organisasi dan disertai dengan pemberian imbalan keuangan oleh organisasi yang bersangkutan. Dari uraian diatas dapat disimpulkan bahwa turnover adalah perpindahan/keluarnya karyawan dari suatu organisasi ke organisasi lainnya disertai dengan pemberian imbalan keuangan. Imbalan keuangan yang wajib dibayarkan oleh pengusaha bila melakukan pemutusan hubungan kerja yang terdiri dari uang pesangon dan atau uang penghargaan masa kerja dan uang pengantian hak yang seharusnya diterima oleh karyawan tersebut (Pasal 156, Undang - Undang NO.13 Tahun 2003 tentang Ketenagakerjaan).

Menurut Hasibuan (2000) turnover karyawan dari perusahaan mempunyai berbagai alasan diantaranya alasan undang-undang, keinginan karyawan, keinginan perusahaan, kontrak kerja berakhir, pensiun, kesehatan karyawan, meninggal dunia, perusahaan dilikuidasi, dari sisi alasan karyawan sendiri diantaranya antara lain pindah ke tempat lain untuk mengurus orang tua atau ikut suami, kesehatan yang kurang baik, melanjutkan pendidikan, berwiraswasta. Tetapi alasan yang sesungguhnya karena gaji terlalu rendah, mendapat pekerjaan yang lebih baik, kesempatan promosi yang tidak ada, suasana dan lingkungan pekerjaan yang kurang cocok, perlakuan yang tidak adil.

Menurut Tofflef Alvin dalam Gillies (1994) menyatakan faktor utama yang menentukan niat keluar yang diikuti dengan pergantian karyawan ialah kurangnya keharmonisan hubungan organisasi dengan tenaga kerja, kebutuhan karyawan akan penghargaan, pengembangan keahlian, sosialisasi, aktualisasi diri dan rencana karir. Menurut Mobley dalam Iman (1982) mengemukakan teori model pengantian karyawan dilihat dari sudut pandang internal organisasi terdiri dari ; ukuran organisasi, kepemimpinan, kompensasi, kepuasan kerja, pengembangan karir, bobot pekerjaan, sentralisasi, sedang faktor individu karyawan terdiri dari ; usia, masa kerja, jenis kelamin, pendidikan, minat, faktor eksternal yaitu ketersedian lapangan kerja.

Menurut Gillis (1994) keluarnya perawat dari rumah sakit dikatakan normal berkisar antara 5 -10 \% per tahun, dikatakan tinggi apabila lebih dari $10 \%$. Menurut Capko (2001), berkisar dibawah $15 \%$ dalam lima tahun berturut-turut, jika lebih dari 20\% maka dikatakan tinggi.

Beberapa hasil penelitian menunjukkan bahwa tingkat turnover di pelayanan kesehatan cukup tinggi seperti pada penelitian Gomez (1995) adalah 72\%, penelitian Sebolt (1978) dalam Gillies (1994) jumlah perawat yang keluar berkisar antara 35\% hingga $60 \%$ pertahun, Duldt (1981) dalam Gillies (1994) sekitar $70 \%$ pertahun. Menurut Ace Sudrajat (2003) angka kejadian perawat yang keluar dari rumah sakit di Indonesia khususnya di rumah sakit Metropolitan Jakarta antara lain: RS UKI perawat keluar rata-rata 23\% pertahun, sedangkan menurut Syafdewiyanti (2002) pada RS Thamrin International Salemba tahun 2000 sebesar $21 \%$ dan tahun 2001 meningkat menjadi $29 \%$.

Berdasarkan data dari Bagian SDM Rumah Sakit Islam "Ibnu Sina" Yarsi Sumbar Bukittinggi sejak tahun 2004 sampai dengan tahun 2010 terdapat 108 orang tenaga perawat yang keluar. Secara rinci persentase turnover dari setiap tahunnya sejak tahun 2004 sampai dengan tahun 2010 berturut turut adalah : 3,9\%, $12,5, \%, 4,5 \%, 6,0 \%, 4,4 \%, 21,3 \%, 24,3 \%$. 
Dimana kecendrungan turnover naik dalam 2 (dua) tahun terakhir (2009 dan 2010) yaitu $21,3 \%$ dan $24,3 \%$. Angka turnover ini melebihi angka normal yang ditetapkan oleh Gillies yaitu $5-10 \%$ per tahun, tentu saja hal ini akan menimbulkan masalah bagi pengelolaan sumber daya manusia khususnya perawat di Rumah Sakit Islam "Ibnu Sina" Yarsi Sumbar Bukittinggi.

Peneliti ingin mengidentifikasi faktorfaktor internal rumah sakit ( ukuran organisasi, kepemimpinan, kompensasi, kepuasan kerja, pengembangan karir, bobot pekerjaan, sentralisasi); faktor individu (usia, masa kerja, jenis kelamin, pendidikan, minat ) dan. faktor eksternal yaitu ketersediaan lapangan kerja dengan kecendrungan turnover perawat di Rumah Sakit Islam "Ibnu Sina" Yarsi Sumbar Bukittinggi.

\section{METODE}

Penelitian ini merupakan penelitian deskriptik analitik dengan pendekatan Cross Sectional Study. Penelitian ini untuk mendapatkan gambaran dan hubungan antara faktor internal organisasi, faktor individu dan faktor eksternal dengan kecendrungan turnover perawat di Rumah Sakit Islam "Ibnu Sina" Yarsi Sumbar Bukittinggi tahun 2011. Data yang menyangkut variabel bebas dan terikat dikumpulkan secara bersamaan (Nursalam, 2008

\section{HASIL DAN PEMBAHASAN}

Hasil analisis univariat persepsi perawat terhadap ukuran organisasi menunjukkan bahwa lebih dari separoh perawat yaitu sebanyak 45 orang $(60 \%)$ menyatakan bahwa rumah sakit ini termasuk organisasi yang kecil. Dari 4 item pernyataan, satu item yang mempunyai nilai terendah adalah birokrasi dan administrasi di rumah sakit yang menyulitkan karyawan dalam menyampaikan aspirasi serta usulan ke bagian manajemen. Usulan dan aspirasi dari karyawan perlu menjadi perhatian bagi pihak manajemen agar dapat menerima masukan - masukan dari karyawan tentang berbagai hal yang ditemui di pelayanan. Banyak hal yang dapat menjadi masukan misalnya tentang kelemahan/ kekurangan dari sistem dan prosedur pelayanan yang telah ditetapkan, sarana yang yang dibutuhkan dalam memberikan pelayanan, masalah yang sering ditemui, serta perbaikan - perbaikan yang di butuhkan. Kejadian yang terjadi di pelayanan tentu akan lebih dirasakan langsung oleh pemberi pelayanan itu sehingga masukan yang diberikan akan lebih bermakna.

Hasil analisis bivariat menujukkan bahwa tidak ada hubungan bermakna antara ukuran organisasi dengan kecendrungan turnover perawat dengan $p$ value 0,256. Selanjutnya dapat dilihat bahwa dari $60 \%$ perawat yang menyatakan rumah sakit merupakan organisasi yang kecil dan $46,7 \%$ perawat yang menyatakan organisasi yang besar ada kecendrungan turnover. Hasil penelitian ini tidak sesuai dengan hasil penelitian Porter dan Steers (1973) dalam Mobley (1986) yang mendapati bahwa organisasi - organisasi yang lebih besar akan mengalami tingkat pergantian yang lebih tinggi yang disebabkan oleh persoalan - persoalan komunikasi, tingkat keterpaduan kelompok yang lebih rendah serta berkurangnya tingkat keluasan pribadi dan birokrasi yang lebih tinggi. Penyebab kecendrungan turnover di Rumah Sakit Islam "Ibnu Sina" Yarsi Sumbar Bukittinggi kemungkinan oleh rumitnya birokrasi di rumah sakit yang menyebabkan perawat mendapat kesulitan dalam menyampaikan usulan- usulannya ke pihak manajemen sehingga menimbulkan kejenuhan terhadap masalah yang yang tidak mendapat penyelesaian yang cepat dan seperti yang diharapkan. 


\section{KESIMPULAN DAN SARAN}

Penelitian yang dilakukan di Rumah Sakit Islam "Ibnu Sina" Yarsi Sumbar Bukittinggi menunjukkan bahwa $54,7 \%$ perawat memiliki kecendrungan turnover, dari ketiga faktor yang mempengaruhi kecendrungan turnover perawat yaitu faktor internal organisasi, faktor individu dan faktor eksternal, hanya ada satu faktor yang mempunyai hubungan bermakna dengan kecendrungan turnover perawat yaitu faktor eksternal - ketersediaan lapangan kerja di institusi lain $(p$ value $\mathbf{0 , 0 3 9}$ ).

1. Untuk Rumah Sakit Islam "Ibnu Sina" Yarsi Sumbar Bukittinggi

Lebih dari separoh perawat yang mempunyai kecendrungan turnover, maka hendaknya menjadi perhatian pimpinan rumah sakit khususnya Bagian Sumber Daya Manusia dan Bidang Perawatan melakukan kajian yang dapat meningkatkan retensi perawat antara lain dengan :

a. Memberikan remunerasi dan atau bonus lainnya serta gaji yang lebih kompetitif sehingga dapat meningkatkan retensi perawat.

b. Merobah cara pemberian pesangon atau THT (Tunjangan Hari Tua) dari satu kali pembayaran waktu karyawan pensiun menjadi pembayaran tiap bulanan dengan program dana pensiun karyawan atau DPLK (Dana Pensiun Lembaga Keuangan), sehingga karyawan yang telah pensiun dapat menerima uang pensiun bulanan seperti halnya Pegawai Negeri.

c. Memperbaharui kembali kontrak kerja karyawan yang baru diangkat menjadi karyawan tetap menjadi beberapa tahun sehingga dapat mengurangi laju turnover.

d. Melakukan rekuitment karyawan dengan lebih selektif, sehingga di dapat karyawan yang berkualitas dan berkomitmen terhadap lembaga Islam yang mempunyai tujuan bekerja bukan hanya untuk kepentingan dunia tetapi juga untuk memajukan lembaga Islam seperti rumah sakit ini.

2. Bagi peneliti selanjutnya

Pada penelitian ini terdapat beberapa keterbatasan penelitian, hasil penelitian yang belum bermakna dan kemungkinan topik - topik lain yang perlu dilanjutkan penelitiannya. Adapun topik -topik yang disarankan untuk diteliti adalah :

a. Mengkaji lebih luas tentang faktorfaktor yang mempengaruhi kecendrungan turnover perawat yang belum dibahas dalam penelitian ini.

Karena penelitian ini sifatnya setempat dan dilakukan di Rumah Sakit Islam "Ibnu Sina" Yarsi Sumbar Bukittinggi yang berkapasitas 144 tempat tidur, maka kemungkinan dapat dilakukan kembali pada rumah sakit swasta lain atau rumah sakit negeri yang lebih besar dengan jumlah responden yang lebih banyak

\section{DAFTAR PUSTAKA}

Arikunto, S(2006). Prosedur penelitian. Jakarta ; Rineka Cipta

Cushway, B. (1994). Human resource management. Terjemahan. Jakarta ; PT Elex Media Komputindo.

Echols, Jhons. M. dan Hassan Shadily. (1975). Kamus Indonesia-Inggris, Jakarta. PT. Gramedia.

Gibson, Ivancevich, Donelly. (1997). Organisasi edisi 5. Terjemahan. Jakarta ; Erlangga.

Gillis, D.A (1989). Nursing management: a system approach. Philadelphia: W.B. Saunder Company.

Gillis, $\begin{array}{ccc}\text { D.A } & \text { (1994). } & \text { Manajemen } \\ \text { keperawatan: } & \text { suatu } & \text { pendekatan }\end{array}$ 
sistem. Edisi ke Tiga. Terjemahan, Philadelphia: W.B. Saunder Company.

Hasibuan, Malayu S.P. (2002). Manajemen sumber daya manusia. Edisi Revisi. Jakarta ; Bumi Aksara.

Hidayat, Aziz Alimul (2008). Manajemen penelitian keperawatan dan teknik analisa data. Jakarta ; Salemba Medika.

Ilyas (2000). Perencanaan sumber daya manusia rumah sakit. Cetakan 1. Depok : Badan Penerbit FKM UI.

Jerris. Linda A. (1999). Human resource management for hospitality. New York; Prentice Hall.

Kepmenkes No 836 tahun 2005 tentang Pedoman pengembangan manajemen kinerja perawat dan bidan.

Kementrian Kesehatan. (1996). Himpunan peraturan perundang-undangan bidang kesehatan. Jakarta. PT Mitra Info.

(2009). Undang-Undang Republik Indonesia No 36 Tahun 2009 Tentang Kesehatan, Jakarta ; Kementrian Kesehatan Republik Indonesia.

-----------, Undang -undang No 13 tahun 2003 tentang Ketenagakerjaan.

Mangkuprawira, S. (2002). Manajemen sumber daya manusia strategi, Jakarta ; Ghalia Indonesia.

Manullang, M. (2006). Dasar-dasar manajemen, Yogyakarta ; Gadjah Mada University Press.

Manullang, Marihot. (2006). Manajemen personalia. Edisi ketiga. Yogyakarta ; Gadjah Mada University Press.

Mobley, WH. (1986). Pergantian karyawan; sebab, akibat dan pengendaliannya. Terjemahan, Jakarta ; PT Gramedia.

Nasution, S. (2002). Metodologi research, penelitian ilmiah. Jakarta ; Bumi Aksara.

Notoatmojo. S.(2005). Metodologi penelitian kesehatan, Edisi Revisi. Jakarta ; Rineka Cipta.

Nursalam dan Pariani. (2001). Metodologi riset keperawatan. Jakarta ; Segung Seto.

Oei, Istijanto. (2005) Riset sumber daya manusia. Jakarta ; PT Gramedia Pustaka Utama.

Panggabean, MS, (2002). Manajemen sumber daya manusia. Jakarta ; Ghalia Indonesia.

Siagian, S.P. (2002), Manajemen sumber daya manusia. Jakarta ; PT. Bumi Aksara.

Sudrajad. Ace. (2003). Faktor - faktor yang berhubungan dengan retensi perawat di Rumah Sakit Agung Jakarta. Tesis. Jakarta. FIK UI. Tidak dipublikasikan.

Suryadi, Endang. (2002). Studi Faktor faktor yang mempengaruhi turnover perawat honorer di RSU Tangerang. Tesis, Jakarta. FKM UI. Tidak dipublikasikan.

Tappen, R.M. (1995). Nursing leadership and managements ; concepts and practice ; Third edition ; Philadelphia. F.A. Davis Company.

Triton. (2007). Manajemen sumber daya manusia, perspektif partnership dan kolektivitas, Yogyakarta ; Tugu Publisher.

Wekley, Kn \& Yulk (1989), Organizational behavior and personal pyscologi, Dalam Shobarudin. M. (1992) Perilaku organisasi dan psikologi personalia, Jakarta ; Rineka Cipta 
